\title{
RESEARCH ARTICLE \\ Effect of Packaging Materials on Storage Quality of Functional Beverage Mix
}

\author{
J. Girija ${ }^{1 *}$ and S. Kamalasundari ${ }^{2}$ \\ ${ }^{1}$ Department of Food Science and Nutrition, Community Science College and Research Institute, \\ Tamil Nadu Agricultural University, Madurai, India. \\ ${ }^{2}$ ICAR - Krishi Vigyan Kendra, Tamil Nadu Agricultural University, Needamangalam, Thiruvarur, India.
}

\begin{abstract}
The present study aimed at development of finger millet-based functional beverage mix with $9 \%$ green banana flour and $1 \%$ ginger powder. The developed beverage mix was packed by using four different packaging materials i.e., low-density polyethylene (P1), standup pouch (P2), aluminium foil pouch (P3) and polyethylene terephthalate bottles (P4) and stored at room temperature. The changes in the physico-chemical, microbial quality were analyzed for 3 months (90 days). The results revealed that during storage, the moisture content was increased from 6.23 to $6.99 \%$, whereas other chemical properties viz., carbohydrate $(\mathrm{CHO})$, protein, fat, ash and dietary fiber were gradually decreased from 68.62 to $68.48,15.09$ to $14.99,1.50$ to 1.48 , 3.74 to 3.73 and 2.78 to 2.77 respectively. There was no signifance change in calcium and phosphorus among the packaging materials during storage. The microbial load was low in P3 and P4 packed beverage mix during storage. The functional beverage mix packed in polyethylene terephthalate bottles was undergone minimum changes in physico-chemical characteristics. Hence, it is concluded that the storage of functional beverage mix in polyethylene terephthalate bottles extended the shelf life of the product and reduced the nutrient losses during storage.
\end{abstract}

Keywords: Finger millet milk powder; Green banana flour; Lactose intolerance; Packaging materials; Storage period.

\section{INTRODUCTION}

Finger millet or ragi (Eleusine coracana) is the oldest cereal grain in India which is fairly grown in extreme climatic conditions such as dry soil and poor fertilizer (Singh et al., 2018). It contains about 5-8\% protein, $65-75 \%$ carbohydrates, $15-20 \%$ dietary fiber and $2.5-3.5 \%$ minerals. It has the highest calcium content among all cereals $(344 \mathrm{mg} / 100$ $\mathrm{g})$, which is thirty times more than that of rice and wheat. However, the millet also contains phytates $(0.48 \%)$, polyphenols, tannins $(0.61 \%)$ (Bansal and Kaur, 2018). These antinutritional properties are removed by using different processing methods such as soaking, germination, boiling and roasting. Due to its nutritional value, this crop is referred as “poor people's crop"(Srivastava and Sharma 2012).

The plant-based foods, especially finger millet, is a very important source of calcium for all age groups. Calcium is one of the primary bone-forming minerals. At birth, an infant has approximately 20 $30 \mathrm{~g}$ calcium and by maturity, the calcium mass is approximately $1200 \mathrm{~g}$, of which approximately 99 $\%$ is present in the bones and teeth. In addition to genetic factors that influence bone mineral density (BMD), the onset of osteoporosis is most often caused by inadequate intake of calcium and Vitamin D. However, other nutrients are also implicated, including phosphorus, magnesium, fluoride, boron, vitamins K, C, potassium and protein (Zalloua et al., 2007). To redress this problem, adequate calcium intake is more important for calcium deficient people (Osteoporosis) and essential for lactose intolerance people. Lactose intolerance is a condition in which people have digestive symptoms such as bloating, diarrhea, and gas after eating or drinking milk or milk products (Harvey et al., 2018). The amount of lactose that causes the symptoms vary from person to person, depending on the amount of lactose consumed, the degree of lactase deficiency and the form of the product/food product in which lactose is ingested. About $75 \%$ of the world's adult population is lactose-intolerant (Deora and Deswal, 2018). The only treatment for people with lactose problems is adherence to foods without lactose. Therefore, taking into account all points, we tried to examine the above considerations before developing functional foods for patients with bone-related diseases and 
lactose intolerance, Hence, the present study aimed to develop plant-based functional beverage mix for lactose intolerance people. Here, instead of using finger millet, finger millet milk powder is used along with other functional ingredients viz., green banana flour and ginger for the preparation of functional beverage and studied the effect of packaging materials [LDPE (P1), standup pouch (P2), Aluminium foil (P3) and PET bottle (P4)] on physico-chemical and microbial quality of the product during 3 months of storage.

\section{MATERIALS AND METHODS:}

\section{Preparation of functional beverage mix}

The raw materials such as finger millet, green banana, and ginger were procured from the local market. All the ingredients were subjected to different required processing steps viz., soaking, blanching, drying, grinding, and roasting. All the ingredients were mixed at standardized proportion for the development of functional beverage mix. The composition of the functional beverage mix is $90 \mathrm{~g}$ of finger millet milk powder, $9 \mathrm{~g}$ of green banana flour and $1 \mathrm{~g}$ of ginger powder.

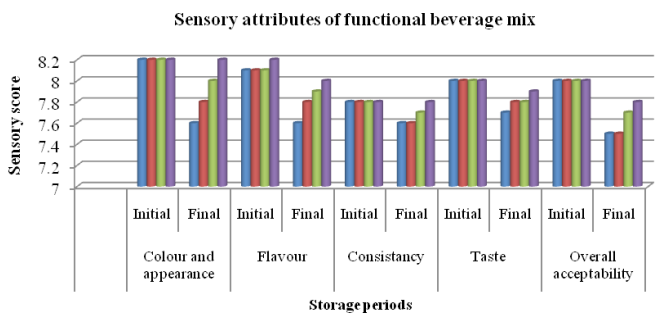

Figure.1 Changes in sensory attributes of functional beverage mix during storage Packaging materials

The packaging materials used for the study are low-density polyethylene, standup pouch (polypropylene), aluminium foil pouch and polyethylene terephthalate (PET) bottle, which are procured from the supermarket in Madurai.

\section{Organoleptic evaluation of beverage mix}

Quality parameters such as color, flavor, texture and overall acceptability of the reconstituted beverage with required sugar $(4 \mathrm{~g})$ from functional beverage mix were evaluated by 20 semi-trained panelists, including lactose intolerance people. Nine points hedonic rating score card was used for organoleptic evaluation of the beverage with the developed mix (Srilakshmi 2005).

\section{Physico-chemical properties}

Moisture, carbohydrate, protein, fat, ash, dietary fiber, calcium and phosphorus were estimated as per standard procedure given by Association of Official Analytical Chemists (AOAC) method.

\section{Microbial quality}

The growth of microorganisms in functional beverage mix was carried out by adopting the standard procedure of serial dilution and pour plate method. One g of sample was added into $9 \mathrm{~mL}$ of sterile water and thoroughly mixed, and then serial dilution was done from 10-1 to 10-6. Here, the 103, 10-1 and 10-1 dilutions were taken and used for further examination of microbes (Bacteria, Fungi and Yeast) in the sample. From this dilution, $1 \mathrm{~mL}$ of sample was poured into Petri plate, and then $15 \mathrm{~mL}$ of required media (nutrient agar media for bacteria, potato dextrose agar media for fungi and yeast) was added for particular microorganism and rotated in the clockwise and anticlockwise direction for uniform spreading of the sample. After solidification of the media, the Petri plates were incubated for $24 \mathrm{~h}$ for bacteria, 2 - 3 days for fungi and 5 days for yeast at ambient temperature. The colonies were examined and expressed as colony-forming units per gram of sample (cfu/ $\mathrm{mL}$ ).

Microbial quality of beverage mix during storage

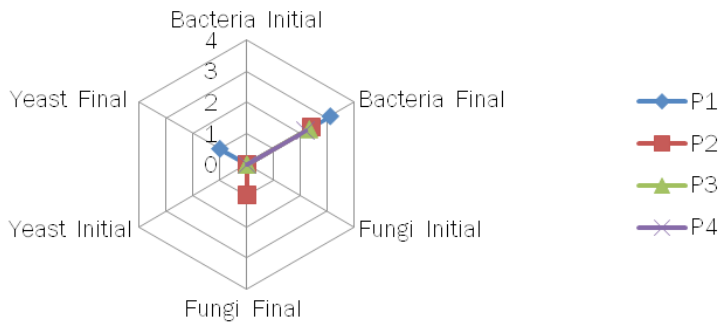

\section{Statistical analysis}

The data observed from the study were subjected to statistical analysis to find out the effect of packaging materials on the quality of the developed product during storage by using AGRES software.

\section{RESULTS AND DISCUSSIONS:}

\section{Organoleptic evaluation of beverage mix during storage}

The sensory attributes of reconstituted beverage from developed functional beverage mix are shown in Figure.1. The slight changes of color and appearance (7.8 - 8.2), flavor (7.8-8.1), consistency (7.6 - 7.8), taste (7.8 - 8.0), and overall acceptability (7.5 - 8.0) observed in P1 and P2 packed beverage mix during 3 months of storage. This might be due to increased moisture content, hydrolysis, and oxidation of nutrients, decreasing its sensory score. There were non-significant changes observed in P3 and P4 packed beverage mix during storage due to less moisture absorption. Arokiamary et al., (2020) stated that supplementary food mix packed with PET jars had highly acceptable sensory scores during the storage period (180 days). Similar findings were reported by Swaminathan and Guha, (2018). 


\section{Physico-chemical properties of beverage mix}

The initial and final moisture content of the functional beverage mix is presented in Table. 1. The initial moisture content of the beverage mix was $6.23 \%$. During storage, the moisture content was increased to a minimum of $6.62 \%$ in P4. Moisture permeability rate was significantly $(p<0.05)$ very low in P3 $(0.39 \%)$ and P4 (0.21 \%) packed samples and higher permeability was shown in $\mathrm{P} 1(0.74 \%)$ and $\mathrm{P} 2$ (0.52\%) packed samples during the storage period, which was checked at regular interval. The increase in moisture content might be due to the absorption of moisture content from the atmosphere via diffusion of vapor from minute pores of packaging materials during the storage period Dhiman et al., (2017). The non-significant difference ( $p>0.05)$ was observed between the packaging material and storage periods. Arokiamary et al., (2020) reported that the moisture content of supplementary food mix packed in PET bottles showed less moisture absorption $(6.35 \%)$ when compared to polyethylene pouches (6.64 \%). Swaminathan and Guha (2018) stated that

the moisture content of rice beverage mix gradually increased from $7.2-7.7 \%$ in 90 days of storage period when packed in aluminium laminate foil (ALF) and metalized polyethylene terephthalate. The ALF-packed rice beverage mix showed low moisture permeability.

Table.1. Physico-chemical properties of beverage mix during storage

\begin{tabular}{lllcccc}
\hline $\begin{array}{c}\text { Physico-chemical } \\
\text { properties }\end{array}$ & \multicolumn{2}{c}{ Moisture } & \multicolumn{2}{c}{ Carbohydrate } & \multicolumn{2}{c}{ Protein } \\
\hline $\begin{array}{l}\text { Packaging } \\
\text { materials }\end{array}$ & \multicolumn{1}{c}{ Initial } & \multicolumn{1}{c}{ Final } & Initial & Final & Initial & Final \\
\hline P1 & 6.23 & 6.99 & 68.62 & 66.85 & 15.09 & 14.92 \\
P2 & 6.23 & 6.95 & 68.62 & 67.19 & 15.09 & 14.95 \\
P3 & 6.23 & 6.93 & 68.62 & 67.32 & 15.09 & 14.98 \\
P4 & 6.23 & 6.62 & 68.62 & 68.48 & 15.09 & 14.99 \\
Particulars & SED & CD (0.05) & SED & CD (0.05) & SED & CD (0.05) \\
P & 0.06773 & $0.13978 * *$ & 0.82199 & $1.169652 \mathrm{NS}$ & 0.13563 & $0.27992 \mathrm{NS}$ \\
S & 0.04789 & $0.09884 N S$ & 0.581124 & $1.19962 \mathrm{NS}$ & 0.09590 & $0.19794 \mathrm{NS}$ \\
PS & 0.09578 & $0.19768 N S$ & 1.16248 & $2.39924 \mathrm{NS}$ & 0.19181 & $0.39587 \mathrm{NS}$ \\
\hline
\end{tabular}

The initial and final carbohydrate content of the beverage mix was found to be $68.62-68.48 \mathrm{~g} / 100 \mathrm{~g}$ in P4. (Table. 1). A very low carbohydrate content was observed among P3 and P4 packed beverage mix. The reduction rate of carbohydrate content was found in different packaging materials and the values are $\mathrm{P} 1$

(1.79 \%), P2 (1.52 \%), P3 (1.13 \%) and P4 (0.14 $\%)$ packed samples. The change in carbohydrate content observed during storage is mainly due to the increasing amount of moisture content which converts the complex sugars into simple sugar. The non-significant difference ( $p>0.05$ ) was observed between the packaging material and storage periods. Sangma et al., (2019) stated that ready to cook malt mix had a carbohydrate content of 72.34 $\mathrm{g} / 100 \mathrm{~g}$ when stored in aluminium foil pouch up to 6 months with good nutrient retention. Similar results were also found in the previous study by Dhiman et al., (2017).

In the first month of storage, the beverage mix had protein content of $15.09 \mathrm{~g} / 100 \mathrm{~g}$, respectively (Table. 1). During storage, the protein content of functional beverage mix got reduced to 0.10 to $0.20 \%$. A gradual decrease of protein content was observed in $\mathrm{P} 1$ and $\mathrm{P} 2$ packaging material compared to P3 and P4 packed beverage mix. The slight decrease in protein content might be due to protein degradation because of increased moisture content and Maillard reaction during storage period. There were no significant changes $(p>0.05)$ observed between packaging materials and the storage period. Dhiman Anju (2017) estimated the protein content of instant mix from dehydrated pumpkin decreased from 10.41 to $9.55 \%$ and concluded that the mix packed in aluminium foil pouch showed more protein retention when compared to polyethylene pouches. Rokhsana et al., (2007) developed the instant pulse-based powder, which had protein content of $19.40 \%$ and reported that the reduction in protein content was very minimum in polyethylene packed powder. These results are highly correlated with the current investigation.

The fat content of the beverage mix was found to be $1.50 \%$ at the initial month of storage period. During storage, the fat content decreased from $1.50-1.45 \%$ (Table. 2). The low reduction was observed in polyethylene terephthalate (PET) packed beverage mix. According to Dhiman Anju (2017), a 
decreased percentage of fat content (6.50 - 6.37\%) was observed in instant halwa mix during six months of storage period. According to Dhiman Anju (2017), the decreased percentage of fat content (6.50 - 6.37 $\%)$ was observed in instant halwa mix packed in LDPE during six months of storage. Dhiman et al., (2017) reported that the fat content of instant soup mix was reduced with an increase in storage period; this was in the range of 1.15 to $1.26 \%$. The slight variation might be due to hydrolysis of fat and the oxidation of flour due to the increasing percent of moisture content during storage. These results are more similar to the present investigation.

The initial dietary fiber content of the control and beverage mix (T4) was 0.70 and $3.74 \%$, respectively (Table. 2). The gradual reduction of dietary fiber was observed during storage that was 0.65 - 3.68 $\%$, which was packed in $\mathrm{P} 1$ and $\mathrm{P} 2$ packaging material, and slight change was observed in P3 and P4 packed beverage mix. The gradual reduction of dietary fiber was observed in all the treatments, but the reduction was slightly lower in P3 $(0.02 \%)$ and P4 (0.01\%) packed samples than P1 (0.07\%) and P2 $(0.05 \%)$ during the storage period. The average reduction rate of dietary fiber among packaging materials was $0.038 \%$ in beverage mix during storage. The non-significant difference $(p>0.05)$ was observed between the packaging material and storage periods. Swaminathan and Guha (2018) stated that the dietary fiber content of protein-rich rice mix is $6.93 \%$ and a very low reduction rate was observed during three months of storage.

The ash content of the beverage mix was found to be $6.90 \mathrm{~g} / 100 \mathrm{~g}$ at the initial month of storage (Table. 2 ). A non-significant reduction ( $p>0.05$ ) in mineral content was observed between packaging materials and storage periods.

Table.2. Physico-chemical properties) of beverage mix during storage

\begin{tabular}{llllcll}
\hline $\begin{array}{c}\text { Physico-chemical } \\
\text { properties }\end{array}$ & \multicolumn{2}{c}{ Fat } & \multicolumn{2}{c}{ Dietary fiber } & & Ash \\
\hline $\begin{array}{c}\text { Packaging } \\
\text { materials }\end{array}$ & \multicolumn{1}{c}{ Initial } & \multicolumn{1}{c}{ Final } & Initial & Final & Initial & Final \\
\hline P1 & 1,50 & 1.45 & 3.74 & 3.68 & 2.78 & 2.75 \\
P2 & 1.50 & 1.46 & 3.74 & 3.72 & 2.78 & 2.75 \\
P3 & 1.50 & 1.47 & 3.74 & 3.72 & 2.78 & 2.76 \\
P4 & 1.50 & 1.48 & 3.74 & 3.73 & 2.78 & 2.77 \\
Particulars & SED & CD $(0.05)$ & SED & CD (0.05) & SED & CD (0.05) \\
P & 0.01097 & $0.02263 \mathrm{NS}$ & 0.03629 & $0.07490 \mathrm{NS}$ & 0.03426 & $0.07071 \mathrm{NS}$ \\
S & 0.00775 & $0.01600 \mathrm{NS}$ & 0.02566 & $0.05296 \mathrm{NS}$ & 0.02423 & $0.05000 \mathrm{NS}$ \\
PS & 0.01551 & $0.03201 \mathrm{NS}$ & 0.05132 & $1.10592 \mathrm{NS}$ & 0.04845 & $0.10000 \mathrm{NS}$ \\
\hline
\end{tabular}

A very minute decrease in mineral contents might be due to the interaction of these with other nutrients like protein and carbohydrate (Hussain et al., 2010). Rokhsana et al., (2007) revealed that there is no reduction observed in the ash content of the sample during 6 months of storage period. A similar trend was observed in

studies of Vashistha et al., (2019). Karuppasamy et al., (2013) reported there was no change observed in ash content $(0.01 \%)$ of the composite mix during 90 days of storage. These findings are more correlated with the current investigation.

\section{Microbial quality of beverage mix during storage:}

The microbial population of beverage mix was carried out during storage period of 3 months at regular intervals. According to observation, there was no growth of bacteria at the initial stage of the developed product in all the packaging materials. In 2nd month no growth was observed in aluminium foil pouches (P3) and PET bottles (P4) packed beverage mix, whereas $\mathrm{P} 1$ and $\mathrm{P} 2$ packed beverage mix had a very low bacterial count that is $1.3 \times 10-3$ and 1.0 $\times 10-3 \mathrm{cfu} / \mathrm{mL}$. The bacterial population slightly increased in all the packaging materials 2.2 - 2.4 $\times 10-3 \mathrm{cfu} / \mathrm{mL}$ respectively for beverage mix at the end of storage month. Arokiamary et al., (2020) stated that the bacterial load of supplementary food mix was found to be $3.0 \times 105 \mathrm{cfu} / \mathrm{g}$, and it was increased to $6.0 \times 105 \mathrm{cfu} / \mathrm{g}$ after 90 days of storage period. Khan et al., (2014) reported that the instant porridge mix had 100 - 150 colonies/ g at initial stage and 200 - 400 colonies/g at 120 days of storage period which was very higher than this study. Senthil et al., (2011) reported that the bacterial count of instant mix ranged from 5.90 - $6.00 \mathrm{Log} 10 \mathrm{cfu} / \mathrm{g}$. It was inferred that the low

$107 \mid 10-12$ | 4 
bacterial count of the beverage mix might be due to low moisture content and the presence of antimicrobial substances in ginger powder.

The fungal growth was not observed in freshly prepared functional beverage mixes. There was no growth of fungi up to 2 months of storage period. In last month of storage, the fungal count was increased slightly in $\mathrm{P} 1$ and $\mathrm{P} 2$ packed beverage mix. The fungal count was found to be $1.0 \times 10-1 \mathrm{cfu} /$ $\mathrm{mL}$ in $\mathrm{P} 1$ and $\mathrm{P} 2$ packed samples at 2 months of storage period. A very low fungal count was observed in during storage that is $1.0 \times 10-1 \mathrm{cfu} / \mathrm{mL}$ in both $\mathrm{P} 1$ and P2 packed beverage mix. There was no fungal count observed in P3 and P4 packed beverage mix. Arokiamary et al., (2020) described that the fungal count of supplementary food mix was observed to be 2.0 - 3.0 x $103 \mathrm{cfu} / \mathrm{g}$ at 60 days of storage period which was higher when compared to the present study. Khan et al., (2014) was noted that there was less than 100 colonies/g of fungal count observed in instant porridge mix during 120 days of storage period. Sudarsan et al., (2017) described that there was no growth of fungal count during one month of storage period. From these findings it is concluded that a very low count was observed in the beverage mix during the storage period, which was found to be within the acceptable limit only.

The yeast count was enumerated in the beverage mix during the storage period at regular intervals. In this there was no count observed up to 2 months of storage period. In 3rd month of the storage period very few counts were observed in $\mathrm{P} 1$ packed beverage mix that is $1.0 \times 10-1 \mathrm{cfu} / \mathrm{mL}$ whereas, no growth showed in P2, P3 and P4 during storage. Arokiamary et al., (2020) reported that in 2 nd month of the storage period, the yeast count of supplementary food mix had 4.0 to $6.0 \times 104 \mathrm{cfu} /$ g. Sudarsan et al., (2017) stated that there was no growth of yeast observed in the instant mix during one month of storage period. Khan et al., (2014) noted that less than 100 colonies of yeast were observed in instant porridge mix during 120 days of storage period.

\section{CONCLUSION:}

The finger millet-based functional beverage mix packed in PET bottle shows minimum changes in physico-chemical, microbial and sensory attributes than the sample packed in other packaging materials low-density polyethylene, standup pouch and aluminium foil pouches. A very low reduction rate of protein, fat, dietary fiber and ash were observed during storage. The samples stored in PET bottles also show minimum changes in the sensory attributes of the functional beverage mix when compared to other packaging materials.

\section{REFERENCE:}

AOAC. 2007. Approved Methods of Association of Official Analytical Chemists. Edited by Gaithersburg. $18^{\text {th }}$ edition ed.

Arokiamary, S., Senthilkumar, R., \& Kanchana, S. 2020. "Influence of Packaging Materials on Storage Quality of Supplementary Food Mix." Current. J. Appl. Sci and Tech., : 134-145.

Bansal, M., \& Kaur, N. 2018. "Sensory and nutritional evaluation of beverages developed using malted ragi (Eleusine coracana)." J. Nat. Appl. Sci. 10 (1):279-286.

Deora, N., \& Deswal, A. 2018. "Non-dairy based beverages: An insight." J. Nutr. Food Res andTech 1 (1):1-4.

Dhiman Anju, K. 2017. "Optimization of instant halwa mix from dehydrated pumpkin and its stability during storage." Inter. J. Agri Sci,, ISSN:0975-3710.

Dhiman, A. K., Vidiya, N., Surekha, A., \& Preethi, R. 2017. "Studies on development and storage stability of dehydrated pumpkin based instant soup mix." J. Appl. Natur. Sci., 9 (3):1815-1820.

Harvey, L., Ludwig, T., Hou, A. Q., Hock, Q. S., Tan, M. L., Osatakul, S., \& Muhardi, L. 2018. Prevalence, cause and diagnosis of lactose intolerance in children aged 1-5 years: a systematic review of 1995-2015 literature. Asia Pac. J. Clin. Nutr., 27(1), 29.

Hussain, Z., Nazir, A., Shafique, U., \& Salman, M. 2010. "Comparative study for the determination of metals in milk samples using flame-AAS and EDTA complexometric titration." J. Sci. Res., 40 (1):1-6.

Karuppasamy, P., Kanchana, S., Hemalatha, G., \& Muthukrishnan, N. 2013. "Development of Sorghum and Maize Based Convenience Mix." Madras Agric. J., 100 (1-3):244-247.

Khan, M. A., Semwal, A. D., Sharma, G. K., \& Bawa, A. S. 2014. "Studies on the optimization and stability of instant wheat porridge (Dalia) mix." J. Food Sci and Tech., 51 (6):1154-1160.

Rokhsana, F., Yeasmin, R., \& Nahar, A. 2007. "Studies on the development and storage stability of legume and vegetable based soup powder." Bangladesh. J. Agr. Res. 32 (3):451-459.

Senthil, A., Mamatha, B. S., Vishwanath, P., Bhat, K. K., \& Ravishankar, G. A. 2011. "Studies on development and storage stability of instant spice adjunct mix from seaweed (Eucheuma)." J. Food Sci and Tech., 48 (6):712-717.

Singh, N., David, J., Thompkinson, D. K., Seelam, B. S., Rajput, H., \& Morya, S. 2018. "Effect of roasting on functional and phytochemical constituents of finger millet (Eleusine coracana L.)." The Pharma Innovation Journal $7^{-}$(4):414-418.

Srilakshmi, B. 2005. "Food Science, chapter 14, food adulteration." New age International (P) Ltd, Publishers 4835:2z4.

Srivastava, K., \& Sharma, A. K. 2012. Nutraceutical importance of finger millet (Eleusine coracana) for improved human health. European J. Plant Sci. Biotech., 6, 91-95. 
Sudarsan, S. M., Santhanam, S. G., \& Visalachi, V. 2017. "Development and formulation of instant soup mix from sprouted horse gram and radish leaves." Int. J. Home Sci., 3 (1): 346-349.

Swaminathan, I., \& Guha, M. 2018. Protein-rich instant rice beverage mix and its quality attributes. J. Food Process and Pres., 42(6), e13628.
Vashistha, Seema, Apoorva Argade, CM Kapoor, and SS Ahlawat. 2019. "Studies on development of milk powder based instant kheer-mix." The. Pharm. Innov. J., 8 (12):61-64.

Zalloua, P. A., Hsu, Y. H., Terwedow, H., Zang, T., Wu, D., Tang, G., \& Xu, X. 2007. "Impact of seafood and fruit consumption on bone mineral density." Maturitas 56 (1):1-11. 